\title{
Assessment of the antioxidant activity of parsley and carob in hypercholesterolemic male rats.
}

\author{
Madeha N. Al-Seeni ${ }^{1}$, Haddad A. El Rabey ${ }^{2,3^{*}}$, Habibah Al-Ghamdi ${ }^{1}$, Abdulbasit I. Al-Sieni ${ }^{1}$, \\ Mohamed I. Sakran ${ }^{2,4}$, Ghena M. Mohammed ${ }^{5}$ \\ ${ }^{1}$ Biochemistry Department, King Abdulaziz University, Jeddah, Kingdom of Saudi Arabia \\ ${ }^{2}$ Biochemistry Department, University of Tabuk, Tabuk, Kingdom of Saudi Arabia \\ ${ }^{3}$ Bioinformatics Department, Genetic Engineering and Biotechnology Research Institute, University Of Sadat City, \\ Sadat City, Egypt \\ ${ }^{4}$ Biochemistry Section, Chemistry Department, Tanta University, Egypt \\ ${ }^{5}$ Department of Nutrition and Food Science, Faculty of Home Science, University of Tabuk, Kingdom of Saudi Arabia
}

\begin{abstract}
Herbal antioxidants have been successfully used to reduce oxidative stress and treat many diseases such as diabetes, obesity and coronary heart diseases. The antioxidant activity of the methanolic extract of carob legume and parsley seed was evaluated in hypercholesterolemic male rats in a study conducted for 8 w. 24 male rats were randomly divided into four 6-rat groups. The $1^{\text {st }}$ group (G1) was fed fat rich diet, the $2^{\text {nd }}$ group (G2) was the hypercholesterolemic positive group fed $2 \%$ cholesterol in the fat rich diet, and the $3^{\text {rd }}(\mathrm{G3})$ and the $4^{\text {th }}(\mathrm{G} 4)$ groups were supplemented with $2 \%$ cholesterol in the fat rich diet as in G2 and co-treated with $20 \mathrm{mg} / \mathrm{Kg}$ bw parsley seeds methanol extract and carob legume methanol extract, respectively. The G2 hypercholesterolemic rats showed significant increase in serum lipid peroxidation and kidney function, and decrease in antioxidants. While the methanolic extract of parsley and carob extract in G3 and G4, respectively significantly decreased lipid peroxidation and kidney functions, and increased antioxidants. In conclusion, the methanolic extracts of both parsley and carob have an antioxidant activity and a protective effect against oxidative stress. The methanolic extract of parsley seed appeared more efficient than that of carob legumes.
\end{abstract}

Keywords: Hypercholesterolemia, Antioxidant, ROS, Rat, Carob, Parsley.

\section{Abbreviations}

ANOVA: Analysis of Variance; BW: Body Weight; CAT: Catalase; G1: Negative control group; G2: Positive control group supplemented with $2 \%$ cholesterol in the fat rich diet; G3: Hypercholesterolemic rats supplemented with $2 \%$ cholesterol and treated with $20 \mathrm{mg} / \mathrm{Kg}$ bw of parsley seeds methanolic extract; G4: Hypercholesterolemic rats supplemented with $2 \%$ cholesterol and treated with $20 \mathrm{mg} / \mathrm{Kg}$ bw of carob legume methanolic extract; GR: Glutathione Reductase activity; GSH: Glutathione Reduced; HDLC: High Density Lipoproteins Cholesterol; LDLc: Low Density Lipoprotein Cholesterol; MDA: Malondialdehyde; SOD: Superoxide Dismutase; TG: Triglyceride; VLDLC: Very Low Density Lipoproteins Cholesterol.

\section{Introduction}

The high level of serum low-density lipoprotein (LDL) and the low level of high density lipoprotein (HDL) are markers for coronary heart diseases [1-3]. In addition, the high fat intake of saturated fatty acids leads to a higher incidence of atherosclerosis and coronary heart disease (CHD) [4].

Alteration in oxidative stress induced by reactive oxygen species (ROS) and impairments of the antioxidant system contributes to the incidence of hypercholesterolemia and subsequent cardiovascular diseases [5]. Free radicals (Reactive
Oxygen Species (ROS)) are products of normal cellular metabolism, and are extremely reactive and potentially damaging transient chemical species [2]. Vaughan et al. [4] and Custodio et al. [6] stated that the process of atherosclerosis begins with the oxidation of low-density lipoprotein cholesterol by free radicals; this is then taken into the lining of the arteries by scavenger cells which form lipid-loaded cells called 'foam cells' that accumulate cholesterol and form fatty streaks, narrowing the arteries. The second reason is primary lipotoxicity caused by oxidative stress from increased lipid 
peroxidation, highly reactive oxygen species production within hepatocytes, mitochondrial dysfunction, and inflammation [7].

Antioxidants are in vivo defense systems, they reduces the oxidative stress by stopping the formation of free radicals, inhibit the formation of reactive oxygen species and reduces hydro peroxides, hydrogen peroxide, singlet oxygen and quenching superoxide formation [8]. The intake of food containing antioxidant compounds protects the low and the very low-density lipoproteins from oxidation and reduces lipid levels in plasma, and thus may reduce the risk of cardiovascular disease [9]. Lipid profile can be ameliorated by adjustment of diet through minimizing consumption of cholesterol and saturated fatty acids, and increasing physical activity [10].

The seeds and taproots of parsley (Petroselinum crispum) possess many therapeutically important constituents such as anti-oxidative, menorrhagic, antimicrobial, anticoagulant, antianemic, antihyperlipidemic, diuretic effects, antihypertensive antihepatotoxic, hypoglycaemic, hypouricemic and estrogenic activities [11]. Furthermore, the major constituents are coumarins, ascorbic acid, flavonoids, phenyl propanoids, phathalides, various terpenoic compounds, carotenoids and tocopherol [12]. Furanocoumarins (psoralen, bergapten, isoimperatorin, oxypeucedanin, xanthoxin, trioxalen and angelicin) are also important constituents of parsley. On the other hand, the essential oil (apiol and myristicin) of parsley is responsible for its toxicity [12].

Carob is the fruit of an evergreen (Ceratonia siliqua L.) is a rich source of minerals, such as potassium, calcium, magnesium, sodium, copper, iron, manganese and zinc [13]. Seven amino acids were extracted from carob pods (alanine, glycine, leucine, proline, and valine, tyrosine and phenylalanine). Also, carob contains insoluble dietary fibers such as cellulose, hemicelluloses and lignin, as well as waterinsoluble polyphenols [14]. The aqueous extract of carob pods decreases lipid peroxidation in the cerebrum and myocardia as well as the level of hydrogen peroxide in liver, brain and kidney, and cannot decrease it in heart [15].

In this study, the antioxidant activity of parsley seed and carob legume methanol extracts was evaluated in hypercholesterolemic male rats.

\section{Materials and Methods}

\section{Tested plant materials}

The seeds of parsley seeds and the legumes of carob were purchased from a herbal medicine shop in Jeddah (Saudi Arabia).

\section{Composition of the fat rich diet}

The diet consisted of $64.6 \%$ corn starch, $16 \%$ casein, $10 \%$ corn oil, $4 \%$ N.N cellulose, $4 \%$ salt mixture, $1 \%$ vitamin mixture, $0.2 \%$ choline chloride and $0.2 \%$ DL methionine.

\section{Animals}

Twenty four (150-200 g) male rats (Rattus norvegicus) of East China origin weighing were purchased from Faculty of Pharmacy, King Abdulaziz University, and Jeddah, Saudi Arabia. The experiments were performed under approved protocol No. 319-34 (The Institutional Animal House of the University of King Abdulaziz at Jeddah, Saudi Arabia).

\section{Housing condition}

The rats were housed six per polycarbonate cage. Cages, bedding and glass water bottles were replaced twice per week. The rats were kept under observation for two weeks before the beginning of the experiment to exclude any undercurrent infection.

\section{Preparation of the methanolic extract}

The methanolic extract of dry parsley seed powder and carob legumes powder was prepared by soaking $200 \mathrm{~g}$ of each in 11 of $90 \%$ methyl alcohol under shaking for $5 \mathrm{~d}$ and then kept in a refrigerator. A rotatory evaporator apparatus attached to a vacuum pump was used to evaporate methanol. Two $\mathrm{ml}$ of suspending agent tween 80 was added to $20 \mathrm{~g}$ of the methyl extract, and then suspended in $100 \mathrm{ml}$ distilled water to prepare a $20 \%$ methanolic extract [16].

\section{Design of the experiment}

The 24 rats were divided randomly into four groups ( $n=6$ rats) as follows: the $1^{\text {st }}$ group (G1) was the negative control group fed fat rich diet, the $2^{\text {nd }}$ group (G2) was the hypercholesterolemic positive control fed $2 \%$ cholesterol in the fat rich diet for $8 \mathrm{w}$ [17]. The $3^{\text {rd }}$ and the $4^{\text {th }}$ groups (G3 and G4) fed $2 \%$ cholesterol as in G2 and co-treated with $20 \mathrm{mg} / \mathrm{Kg}$ bw parsley seeds and carob legumes methanolic extracts using stomach tube, respectively.

\section{Blood collection}

For biochemical analysis, at the end of the experiment, blood was collected from fasted animals (14-16 $\mathrm{h}$ after their last feeding) from the heart of dimethyl-ether pre-anaesthetized rats in plain tubes. Serum was obtained by centrifugation at 1000 rpm for $10 \mathrm{~min}$ at room temperature, and then stored at $-20^{\circ} \mathrm{C}$ until analysis. To estimate the antioxidant and lipid peroxidation in liver and heart tissue homogenate, the abdomen was opened and the heart and the liver were saved in ice-cold for tissue homogenate preparation.

\section{Tissue homogenate preparation}

Heart and liver tissue homogenates were prepared according to the method described in Abulnaja et al. [2] from ice cold liver and heart tissues. 


\section{Estimation of serum proteins}

A spectrophotometrica method was used in quantification of proteins as described by Peterson [18] using Sigma kit (USA). Serum albumin was also estimated spectrophotometrically according to the method described by Rebecca [19] using Sigma-Aldrich (USA) kit. Serum globulin was calculated as follows: serum globulin $(\mathrm{g} / \mathrm{dl})=$ total protein $(\mathrm{g} / \mathrm{dl})$-albumin $(\mathrm{g} /$ dl).

\section{Total bilirubin estimation}

The total bilirubin was estimated spectrophotometrically using spectrum kit (Germany) as described by Balistreri et al. [20].

\section{Kidney function}

Urea and uric acid were estimated in serum spectrophotometrically according to the method described by Fawcett et al. [21], Fossati et al. [22], respectively using Human kit (Germany), whereas creatinine was estimated according to the method described by Tietz [23] using Moody International creatinine kit, UKAS (Germany).

\section{Serum electrolytes $\left(\mathrm{Na}^{+}\right.$and $\left.\mathrm{K}^{+}\right)$estimation}

Sodium and potassium ions $\left(\mathrm{Na}^{+}\right.$and $\left.\mathrm{K}^{+}\right)$were estimated in serum colorimetrically using Electrolytes Test Kit (India) according to Schoenfeld et al. [24] and Terri et al. [25], respectively.

\section{Estimation of antioxidants and lipid peroxidation}

The activities of serum, and heart and liver tissue homogenate of non-enzymatic glutathione reduced (GSH), and the antioxidant enzymes catalase (CAT) and superoxide dismutase (SOD) were assayed colorimetrically according to Beutler et al. [26], Aebi [27] and Nishikimi et al. [28], respectively using Biodiagnostic kit (Egypt). In addition, glutathione reductase activity (GR) was also assayed spectrophotometrically in serum, and liver and heart tissue homogenate according to the method described by Goldberg et al. [29] using Biodiagnostic kit (Egypt). Lipid peroxidation was also estimated in serum, and liver and heart tissue homogenate by measuring the value of malondialdehyde (MDA) according to the colorimetric method of Satoh [30] using Biodiagnostic kit (Egypt), too.

\section{Statistical analysis}

The SPSS program was used to calculate mean values, standard error and test of significance, whereas, one way analysis of variance of SAS package was used to calculate the least significant difference and Analysis of Variance (ANOVA).

\section{Results}

\section{Total bilirubin}

Table 1 shows the effect of administration of $20 \mathrm{mg} / \mathrm{Kg}$ bw of parsley and carob methanolic extracts for $8 \mathrm{w}$ on serum total bilirubin in hypercholesterolemic male rats. Bilirubin was nonsignificantly increased in G2 as a result of hypercholesterolemia. After treatment with $20 \mathrm{mg} / \mathrm{Kg}$ bw of parsley and carob methanolic extracts for $8 \mathrm{w}$ in G3 and G4, respectively the level of total bilirubin was nonsignificantly decreased in both groups approaching the negative control.

\section{Serum protein}

Table 1 also shows the effect of administration of $20 \mathrm{mg} / \mathrm{Kg}$ bw of parsley and carob methanolic extracts for $8 \mathrm{w}$ on serum proteins in hypercholesterolemic rats. The total protein (albumin, globulin, and their $\mathrm{A} / \mathrm{G}$ ratio) were nonsignificantly decreased by hypercholesterolemia in G2 and nonsiginificantly increased by the concurrent supplementation with $20 \mathrm{mg} / \mathrm{Kg}$ bw of parsley seed methanolic extract in G3 and $20 \mathrm{mg} / \mathrm{Kg}$ bw of carob legume methanolic extract in G4 approaching the negative control.

Table 1. Effect of administration of $20 \mathrm{mg} / \mathrm{Kg}$ bw of parsley and carob methanolic extracts for $8 \mathrm{w}$ on serum total protein and bilirubin in hypercholesterolemic male rats.

\begin{tabular}{|c|c|c|c|c|c|c|}
\hline Parameters & Statistics & $\begin{array}{l}\text { Negative control } \\
\text { group (G1) }\end{array}$ & $\begin{array}{l}\text { Positive } \quad \text { control } \\
\text { group (G2) }\end{array}$ & $\begin{array}{l}20 \mathrm{mg} / \mathrm{Kg} \text { bw of parsley } \\
\text { methanol extract (G3) }\end{array}$ & $\begin{array}{l}20 \mathrm{mg} / \mathrm{Kg} \text { bw of } \\
\text { methanol extract (G4) }\end{array}$ & carob \\
\hline \multirow[t]{3}{*}{ Total bilirubin (mg/dl) } & Mean \pm SE & $0.49 \pm 0.07^{a}$ & $0.55 \pm 0.06^{\mathrm{a}}$ & $0.48 \pm 0.06^{a}$ & $0.52 \pm 0.05^{a}$ & \\
\hline & LSD $0.05=0.198$ & & & & & \\
\hline & t-test & - & $-0.51 \mathrm{NS}$ & $0.63 \mathrm{NS}$ & $0.42 \mathrm{NS}$ & \\
\hline \multirow[t]{3}{*}{ Total protein $\mathrm{g} / \mathrm{dl}$} & Mean \pm SE & $6.48 \pm 0.09^{a}$ & $6.26 \pm 0.21^{a}$ & $6.43 \pm 0.11^{a}$ & $6.47 \pm 0.09^{a}$ & \\
\hline & LSD $0.05=0.465$ & & & & & \\
\hline & t-test & - & $0.98 \mathrm{NS}$ & $-0.60 \mathrm{NS}$ & $-0.72 \mathrm{NS}$ & \\
\hline \multirow[t]{3}{*}{ Albumin (g/dl) } & Mean \pm SE & $4.28 \pm 0.14^{a}$ & $4.06 \pm 0.16^{\mathrm{a}}$ & $4.11 \pm 0.13^{a}$ & $4.23 \pm 0.13^{a}$ & \\
\hline & LSD $0.05=0.393$ & & & & & \\
\hline & t-test & - & $1.73 \mathrm{NS}$ & $-0.20 \mathrm{NS}$ & $-0.62 \mathrm{NS}$ & \\
\hline
\end{tabular}




\begin{tabular}{|c|c|c|c|c|c|}
\hline \multirow[t]{3}{*}{ Globulin (g/dl) } & Mean \pm SE & $2.31 \pm 0.15^{\mathrm{a}}$ & $2.19 \pm 0.26^{a}$ & $2.36 \pm 0.11^{a}$ & $2.23 \pm 0.06^{a}$ \\
\hline & \multicolumn{5}{|c|}{ LSD $0.05=0.750$} \\
\hline & t-test & - & $0.60 \mathrm{NS}$ & $-0.60 \mathrm{NS}$ & $-0.15 \mathrm{NS}$ \\
\hline \multirow[t]{3}{*}{$\mathrm{A} / \mathrm{G}$ ratio } & Mean \pm SE & $1.85 \pm 0.15^{\mathrm{a}}$ & $1.85 \pm 0.58^{a}$ & $1.74 \pm 0.14^{a}$ & $1.89 \pm 0.10^{a}$ \\
\hline & \multicolumn{5}{|c|}{ LSD $0.05=0.399$} \\
\hline & t-test & - & $-1.01 \mathrm{NS}$ & $1.02 \mathrm{NS}$ & $1.00 \mathrm{NS}$ \\
\hline
\end{tabular}

Data are represented as mean $\pm \mathrm{SE}$. t-test values; ${ }^{* * *}$ significant at $\mathrm{P}<0.001$. ANOVA analysis: within each row, means with different superscript $(\mathrm{a}, \mathrm{b}, \mathrm{c}$ or $\mathrm{d})$ are significantly different at $P<0.05$, whereas means superscripts with the same letters mean that there is no significant difference at $P>0.05$. LSD: Least Significant Difference.

\section{Kidney function}

Table 2 shows the effect of administration of $20 \mathrm{mg} / \mathrm{Kg}$ bw of parsley and carob methanolic extracts for $8 \mathrm{w}$ on kidney function in hypercholesterolemic male rats. Serum uric acid, creatinine and urea in G2 were significantly increased (at $<0.001$ for uric acid and creatinine, and at $\mathrm{P}<0.05$ in urea). The concurrent supplementation of $20 \mathrm{mg} / \mathrm{Kg}$ bw of parsley and carob methanolic extracts for $8 \mathrm{w}$ in G3 and G4, respectively significantly decreased serum uric acid and creatinine compared to G2 approaching the negative control G1. Whereas serum urea was non-significantly decreased in both G3 and G4. Parsley seed methanolic extract was more efficient than carob legumes methanol extract in restoring the altered kidney function indices.

Table 2. Effect of administration of $20 \mathrm{mg} / \mathrm{Kg}$ bw of parsley and carob methanolic extracts for $8 \mathrm{w}$ on kidney functions and serum electrolytes (Na ${ }^{+}$ and $\mathrm{K}^{+}$) in hypercholesterolemic male rats.

\begin{tabular}{|c|c|c|c|c|c|}
\hline Parameters & Statistics & $\begin{array}{l}\text { Negative control group } \\
\text { (G1) }\end{array}$ & $\begin{array}{l}\text { Positive control group } \\
\text { (G2) }\end{array}$ & $\begin{array}{l}20 \mathrm{mg} / \mathrm{Kg} \text { bw of parsley } \\
\text { methanol extract (G3) }\end{array}$ & $\begin{array}{l}20 \mathrm{mg} / \mathrm{Kg} \text { bw of carob } \\
\text { methanol extract (G4) }\end{array}$ \\
\hline \multirow[t]{3}{*}{ Uric acid (mg/dl) } & Mean \pm SE & $4.11 \pm 0.04^{b}$ & $4.35 \pm 0.04^{a}$ & $4.15 \pm 0.06^{b}$ & $4.18 \pm 0.07^{a}$ \\
\hline & LSD $0.05=0.126$ & & & & \\
\hline & t-test & - & $-4.62^{* \star *}$ & **3.26 & $* \star 5.65$ \\
\hline \multirow[t]{3}{*}{ Creatinine (mg/dl) } & Mean \pm SE & $0.55 \pm 0.02^{\mathrm{c}}$ & $0.77 \pm 0.03^{a}$ & $0.60 \pm 0.02^{b c}$ & $0.63 \pm 0.02^{b}$ \\
\hline & LSD $0.05=0.071$ & & & & \\
\hline & t-test & - & $-5.30^{* * *}$ & $10.51^{* * *}$ & *2.95 \\
\hline \multirow[t]{3}{*}{ Urea (mg/dl) } & Mean \pm SE & $20.78 \pm 0.88^{b}$ & $24.73 \pm 1.30^{a}$ & $23.01 \pm 0.35^{\mathrm{ab}}$ & $24.23 \pm 0.11^{b}$ \\
\hline & LSD $0.05=2.339$ & & & & \\
\hline & t-test & - & $-2.84^{*}$ & $1.26 \mathrm{NS}$ & $0.39 \mathrm{NS}$ \\
\hline \multirow[t]{3}{*}{$\mathrm{Na}^{+}(\mathrm{mmol} / \mathrm{l})$} & Mean \pm SE & $140.00 \pm 0.42^{a}$ & $140.67 \pm 0.61^{a}$ & $140.17 \pm 0.45^{a}$ & $140.50 \pm 0.87^{a}$ \\
\hline & LSD $0.05=1.837$ & & & & \\
\hline & t-test & - & $-0.71 \mathrm{NS}$ & $0.82 \mathrm{NS}$ & $0.21 \mathrm{NS}$ \\
\hline \multirow[t]{3}{*}{$\mathrm{K}^{+}(\mathrm{mmol} / \mathrm{l})$} & Mean \pm SE & $4.75 \pm 0.04^{a}$ & $4.70 \pm 0.05^{a}$ & $4.71 \pm 0.04^{a}$ & $4.73 \pm 0.06^{a}$ \\
\hline & LSD $0.05=0.171$ & & & & \\
\hline & t-test & - & $0.59 \mathrm{NS}$ & $-0.19 \mathrm{NS}$ & $-0.37 \mathrm{NS}$ \\
\hline
\end{tabular}

Data are represented as mean $\pm S E$. t-test values *significant at $P<0.05,{ }^{* *}$ significant at $P<0.01,{ }^{* * *}$ significant at $P<0.001$. ANOVA analysis: within each row, means with different superscript (a-d) are significantly different at $P<0.05$, whereas means superscripts with the same letters mean that there is no significant difference at $P>0.05$. LSD: Least Significant Difference, N.S: Non-Significant.

\section{Serum electrolytes}

Table 2 also shows the effect of administration of $20 \mathrm{mg} / \mathrm{Kg}$ bw of parsley and carob methanolic extracts for $8 \mathrm{w}$ on serum $\mathrm{Na}^{+}$and serum $\mathrm{K}^{+}$in hypercholesterolemic male rats. The levels of $\mathrm{Na}^{+}$and $\mathrm{K}^{+}$in the serum were non-significantly affected either by induced hypercholesterolemia in G2 or treating with $20 \mathrm{mg} / \mathrm{kg}$ bw of parsley and carob methanolic extracts for $8 \mathrm{w}$ in $\mathrm{G} 3$ and $\mathrm{G} 4$, respectively. 


\section{Serum antioxidants}

Table 3 shows the effect of administration of $20 \mathrm{mg} / \mathrm{Kg}$ bw of parsley and carob methanolic extracts for $8 \mathrm{w}$ on serum antioxidants enzymes in hypercholesterolemic male rats. The oral administration of $2 \%$ cholesterol in $\mathrm{G} 2$ for $8 \mathrm{w}$ significantly (at $<0.001$ ) decreased serum catalase, SOD, GSH, and GR. The concurrent supplementation with $20 \mathrm{mg} / \mathrm{kg}$ bw of parsley seed methanolic extract in G3 and carob legume methanol extract in G4 significantly (at <0.001) increased serum catalase, SOD, GSH, and GR in the hypercholesterolemic male rats. Parsley seed methanolic extract was more efficient than carob legume methanol extract in restoring the antioxidants activity.

Table 3. Effect of administration of administration of $20 \mathrm{mg} / \mathrm{Kg}$ bw of parsley and carob methanol extracts for $8 \mathrm{w}$ on serum antioxidants in hypercholesterolemic male rats.

\begin{tabular}{|c|c|c|c|c|c|}
\hline Parameters & Statistics & $\begin{array}{l}\text { Negative control group } \\
\text { (G1) }\end{array}$ & $\begin{array}{l}\text { Positive control group } \\
\text { (G2) }\end{array}$ & & $\begin{array}{l}20 \mathrm{mg} / \mathrm{kg} \text { bw of carob } \\
\text { methanol extract (G4) }\end{array}$ \\
\hline \multirow[t]{3}{*}{ Catalase $(\mathrm{U} / \mathrm{ml})$} & Mean \pm SE & $2.00 \pm 0.05^{a}$ & $0.20 \pm 0.01^{d}$ & $1.45 \pm 0.08^{b}$ & $0.47 \pm 0.02^{c}$ \\
\hline & LSD $0.05=0.175$ & & & & \\
\hline & t-test & - & ${ }^{* \star *} 26.48$ & ${ }^{* * *}-12.87$ & ${ }^{* * *}-6.09$ \\
\hline \multirow[t]{3}{*}{ Superoxide dismutase $(\mathrm{U} / \mathrm{ml})$} & Mean \pm SE & $312.60 \pm 4.35^{a}$ & $127.63 \pm 1.72^{\mathrm{d}}$ & $242.47 \pm 3.14^{b}$ & $188.60 \pm 2.28^{c}$ \\
\hline & LSD $0.05=8.504$ & & & & \\
\hline & t-test & - & ***39.93 & ${ }^{* * \star}-38.22$ & ${ }^{* \star *}-44.81$ \\
\hline \multirow{3}{*}{$\begin{array}{l}\text { Glutathione reduced }(\mathrm{GSH}) \\
(\mathrm{mmol} / \mathrm{ml})\end{array}$} & Mean \pm SE & $162.57 \pm 40.74^{a}$ & $36.84 \pm 2.62^{d}$ & $136.64 \pm 14.80^{b}$ & $100.81 \pm 22.45^{c}$ \\
\hline & LSD $0.05=79.110$ & & & & \\
\hline & t-test & - & $92.22^{\star \star \star}$ & ${ }^{\star \star *}-187.30$ & ${ }^{* \star *}-87.68$ \\
\hline \multirow{3}{*}{$\begin{array}{l}\text { Glutathione reductase (GR) } \\
(\mathrm{U} / \mathrm{ml})\end{array}$} & Mean \pm SE & $5.90 \pm 0.22^{a}$ & $1.36 \pm 0.08^{d}$ & $4.63 \pm 0.11^{b}$ & $3.11 \pm 0.11^{c}$ \\
\hline & LSD $0.05=0.359$ & & & & \\
\hline & t-test & - & ${ }^{* * *} 21.18$ & ${ }^{* * *}-22.48$ & ${ }^{* * *}-15.65$ \\
\hline
\end{tabular}

\section{Antioxidant enzymes in liver and heart tissues homogenate}

Tables 4 and 5 show the effect of $20 \mathrm{mg} / \mathrm{kg}$ bw of parsley and carob methanolic extracts for $8 \mathrm{w}$ on antioxidant enzymes in liver and heart tissues homogenate of hypercholesterolemic male rats. Catalase, SOD, GSH, and GR in the liver and heart tissues homogenate were significantly (at $<0.001$ ) decreased in the positive control group (G2) as a result of cholesterol administration for $8 \mathrm{w}$. The concurrent supplementation with $20 \mathrm{mg} / \mathrm{Kg}$ bw of parsley and carob methanolic extracts for $8 \mathrm{w}$ in $\mathrm{G} 3$ and $\mathrm{G} 4$, respectively significantly (at $<0.001$ ) increased catalase, SOD, GSH, and GR in the liver and heart tissue homogenate in the hypercholesterolemic rats. Parsley seeds methanolic extract was more efficient than carob legume methanol extract.

Table 4. Effect of administration of $20 \mathrm{mg} / \mathrm{Kg}$ bw of parsley and carob methanol extracts for $8 \mathrm{w}$ on liver tissue homogenate antioxidants in hypercholesterolemic rats.

\begin{tabular}{|c|c|c|c|c|c|}
\hline Parameters & Statistics & $\begin{array}{l}\text { Negative control group } \\
\text { (G1) }\end{array}$ & $\begin{array}{l}\text { Positive } \\
\text { group (G2) }\end{array}$ & $\begin{array}{l}20 \mathrm{mg} / \mathrm{kg} \text { bw of parsley } \\
\text { methanol extract (G3) }\end{array}$ & $\begin{array}{l}20 \mathrm{mg} / \mathrm{kg} \text { bw of carob } \\
\text { methanol extract (G4) }\end{array}$ \\
\hline \multirow[t]{3}{*}{ Catalase $(\mathrm{U} / \mathrm{g})$} & Mean \pm SE & $5.36 \pm 0.11^{\mathrm{a}}$ & $0.88 \pm 0.02^{d}$ & $3.95 \pm 0.13^{b}$ & $2.86 \pm 0.10^{c}$ \\
\hline & LSD $0.05=0.314$ & & & & \\
\hline & t-test & - & ${ }^{* * *} 44.65$ & ${ }^{* * *}-19.85$ & ${ }^{* * *}-16.46$ \\
\hline \multirow{3}{*}{$\begin{array}{l}\text { Superoxide } \\
(\mathrm{U} / \mathrm{g})\end{array}$} & Mean \pm SE & $1014.50 \pm 10.57^{a}$ & $562.68 \pm 3.61^{d}$ & $822.45 \pm 5.33^{b}$ & $629.58 \pm 6.26^{c}$ \\
\hline & LSD $0.05=20.822$ & & & & \\
\hline & t-test & - & ${ }^{* * *} 33.15$ & ${ }^{* * *}-54.08$ & ${ }^{* * *}-13.26$ \\
\hline $\begin{array}{l}\text { Glutathione } \\
(\mathrm{mmol} / \mathrm{g})\end{array}$ & Mean \pm SE & $262.4 \pm 24.57^{a}$ & $143.92 \pm 34.67^{c}$ & $214.86 \pm 28.61^{b}$ & $190.68 \pm 17.12^{d}$ \\
\hline
\end{tabular}




\begin{tabular}{|c|c|c|c|c|c|c|}
\hline & & LSD $0.05=66.134$ & & & & \\
\hline & & t-test & - & $103.20^{\star \star \star}$ & ${ }^{* * *}-47.50$ & $* * * 71.34$ \\
\hline \multirow{3}{*}{$\begin{array}{l}\text { Glutathione } \\
(\mathrm{U} / \mathrm{g})\end{array}$} & \multirow[t]{3}{*}{ reductase } & Mean \pm SE & $9.41 \pm 0.08^{a}$ & $3.13 \pm 0.12^{d}$ & $6.37 \pm 0.10^{b}$ & $5.60 \pm 0.13^{c}$ \\
\hline & & LSD $0.05=0.305$ & & & & \\
\hline & & t-test & - & ${ }^{* * *} 40.89$ & ${ }^{* * *}-33.02$ & $* * *-17.54$ \\
\hline
\end{tabular}

Data are represented as mean \pm SE. t-test values: ${ }^{* * *}$ : significant at $P<0.001$. ANOVA analysis: within each row, means with different superscript $(a-d)$ are significantly different at $P<0.05$, whereas means superscripts with the same letters mean that there is no significant difference at $P>0.05$. LSD: Least Significant Difference.

Table 5. Effect of $20 \mathrm{mg} / \mathrm{kg}$ bw of parsley and carob methanol extracts for $8 \mathrm{w}$ on antioxidants of heart tissue in hypercholesterolemic male rats.

\begin{tabular}{|c|c|c|c|c|c|}
\hline Parameters & Statistics & $\begin{array}{l}\text { Negative control group } \\
\text { (G1) }\end{array}$ & $\begin{array}{l}\text { Positive control } \\
\text { group (G2) }\end{array}$ & $\begin{array}{l}20 \mathrm{mg} / \mathrm{Kg} \text { bw of parsley } \\
\text { methanol extract (G3) }\end{array}$ & $\begin{array}{l}20 \mathrm{mg} / \mathrm{Kg} \text { bw of carob } \\
\text { methanol extract (G4) }\end{array}$ \\
\hline \multirow[t]{3}{*}{ Catalase (CAT) (U/g) } & Mean \pm SE & $4.51 \pm 0.07^{a}$ & $0.69 \pm 0.02^{d}$ & $3.60 \pm 0.15^{b}$ & $2.15 \pm 0.10^{c}$ \\
\hline & LSD $0.05=0.309$ & & & & \\
\hline & t-test & - & ${ }^{* * *} 58.36$ & $* * *-19.96$ & $* * *-12.35$ \\
\hline \multirow{3}{*}{$\begin{array}{l}\text { Superoxide dismutase (SOD) } \\
(\mathrm{U} / \mathrm{g})\end{array}$} & Mean \pm SE & $9415.30 \pm 21.32^{\mathrm{a}}$ & $4296.20 \pm 35.81^{d}$ & $6567.70 \pm 21.58^{c}$ & $5417.50 \pm 15.65^{c}$ \\
\hline & LSD $0.05=84.917$ & & & & \\
\hline & t-test & - & ${ }^{\star * *} 102.95$ & $\star * \star-42.44$ & ${ }^{* * *}-24.28$ \\
\hline \multirow{3}{*}{$\begin{array}{l}\text { Glutathione reduced }(\mathrm{GSH}) \\
(\mu \mathrm{mol} / \mathrm{g})\end{array}$} & Mean \pm SE & $247.14 \pm 14.88^{a}$ & $139.21 \pm 10.72^{d}$ & $201.78 \pm 8.78^{b}$ & $171.42 \pm 13.70^{c}$ \\
\hline & LSD $0.05=36.469$ & & & & \\
\hline & t-test & - & $140.74^{\star \star \star}$ & ${ }^{\star * *}-114.75$ & $* *-47.86$ \\
\hline \multirow{3}{*}{$\begin{array}{l}\text { Glutathione reductase }(\mathrm{GR}) \\
(\mathrm{U} / \mathrm{g})\end{array}$} & Mean \pm SE & $8.58 \pm 0.10^{\mathrm{a}}$ & $2.20 \pm 0.12^{d}$ & $6.16 \pm 0.08^{c}$ & $7.50 \pm 0.05^{b}$ \\
\hline & LSD $0.05=0.296$ & & & & \\
\hline & t-test & - & ${ }^{* * *} 41.54$ & $* * 26.09$ & ${ }^{* * *}-32.05$ \\
\hline
\end{tabular}

Data are represented as mean \pm SE. t-test values: ${ }^{* *}$ significant at $\mathrm{P}<0.001$. ANOVA analysis: within each row, means with different superscript (a-d) are significantly different at $P<0.05$, whereas means superscripts with the same letters mean that there is no significant difference at $P>0.05$. LSD: Least Significant Difference.

\section{Lipid peroxidation}

Table 6 shows the effect of $20 \mathrm{mg} / \mathrm{kg}$ bw of parsley and carob methanolic extracts for $8 \mathrm{w}$ on lipid peroxide in serum, and liver and heart tissue homogenate in hypercholesterolemic male rats. The lipid peroxidation in the serum, liver and heart tissue homogenate were significantly (at $<0.001$ ) increased in the positive control group (G2), as a result of cholesterol supplementation for $8 \mathrm{w}$. The concurrent supplementation with $20 \mathrm{mg} / \mathrm{kg}$ bw of parsley seeds methanolic extract in G3 and carob legume methanolic extract in G4 significantly (at $<0.001$ ) decreased lipid peroxidation in the hypercholesterolemic rats. Parsley seed methanolic extract was also more efficient in reducing oxidative stress as revealed by MDA levels.

Table 6. Effect of administration of $20 \mathrm{mg} / \mathrm{kg}$ bw of parsley and carob methanol extracts for $8 w$ on lipid peroxidation in hypercholesterolemic male rats.

\begin{tabular}{llllll}
\hline Parameters Statistics & $\begin{array}{l}\text { Negative } \\
\text { control }\end{array}$ & $\begin{array}{l}\text { Positive } \\
\text { control }\end{array}$ & $\begin{array}{l}20 \mathrm{mg} / \mathrm{kg} \\
\text { bw of }\end{array}$ \\
parsley & $\begin{array}{l}20 \mathrm{mg} / \mathrm{kg} \\
\text { carob }\end{array}$
\end{tabular}

\begin{tabular}{|c|c|c|c|c|c|c|}
\hline & & $\begin{array}{l}\text { group } \\
\text { (G1) }\end{array}$ & & $\begin{array}{l}\text { group } \\
\text { (G2) }\end{array}$ & $\begin{array}{l}\text { methanol } \\
\text { extract } \\
\text { (G3) }\end{array}$ & $\begin{array}{l}\text { methanol } \\
\text { extract } \\
\text { (G4) }\end{array}$ \\
\hline \multirow[t]{3}{*}{$\begin{array}{l}\text { Plasma } \\
(\mathrm{nmol} / \mathrm{ml})\end{array}$} & Mean \pm SE & $\begin{array}{l}1.400 \\
0.131^{\mathrm{d}}\end{array}$ & \pm & $\begin{array}{l}8.281 \\
0.169 \text { a }\end{array}$ & $\begin{array}{l}5.200 \\
0.196^{\mathrm{b}}\end{array}$ & $\begin{array}{l}2.833 \\
0.144^{\mathrm{C}}\end{array} \quad \pm$ \\
\hline & $\begin{array}{l}\text { LSD } \\
0.05=0.460 \\
5\end{array}$ & & & & & \\
\hline & t-test & - & & $-31.162^{* \star *}$ & *** 10.781 & ${ }^{* * *} 33.342$ \\
\hline \multirow[t]{3}{*}{$\begin{array}{l}\text { Liver } \\
(\mathrm{nmol} / \mathrm{g})\end{array}$} & Mean \pm SE & $\begin{array}{l}8.766 \\
0.367^{d}\end{array}$ & \pm & $\begin{array}{l}26.983 \quad \pm \\
0.439^{a}\end{array}$ & $\begin{array}{l}20.966 \quad \pm \\
0.454^{\mathrm{b}}\end{array}$ & $\begin{array}{l}15.900 \quad \pm \\
0.367^{\mathrm{c}}\end{array}$ \\
\hline & $\begin{array}{l}\text { LSD } \\
0.05=1.227\end{array}$ & & & & & \\
\hline & t-test & - & & $-32.668^{* \star *}$ & ${ }^{* * *} 9.230$ & ${ }^{* * *} 22.517$ \\
\hline \multirow[t]{3}{*}{$\begin{array}{l}\text { Heart } \\
(\mathrm{nmol} / \mathrm{g})\end{array}$} & Mean \pm SE & $\begin{array}{l}6.366 \\
0.348^{d}\end{array}$ & \pm & $\begin{array}{l}22.716 \quad \pm \\
0.578^{a}\end{array}$ & $\begin{array}{l}17.016 \quad \pm \\
0.258^{\mathrm{b}}\end{array}$ & $\begin{array}{l}10.466 \quad \pm \\
0.326^{\mathrm{c}}\end{array}$ \\
\hline & $\begin{array}{l}\text { LSD } \\
0.05=1.196 \\
9\end{array}$ & & & & & \\
\hline & t-test & - & & $-23.393^{\star \star \star}$ & $8.909^{\star \star \star}$ & ${ }^{* * *} 16.343$ \\
\hline
\end{tabular}


Data are represented as mean \pm SE. t-test values: ${ }^{* * *}$ significant at $\mathrm{P}<0.001$ ANOVA analysis: within each row, means with different superscript (a-d) are significantly different at $\mathrm{P}<0.05$, whereas means superscripts with the same letters mean that there is no significant difference at $P>0.05$. LSD: Least Significant Difference.

\section{Discussion}

Feeding rats with $2 \%$ cholesterol in the fat rich diet for two months induce hypercholesterolemia causing elevated total cholesterol, low-density lipoprotein (LDL), very low-density lipoprotein (VLDL) and decreased high-density lipoprotein (HDL) $[2,3,17,31]$. In this study, the total protein, albumins, globulins, albumins/globulins ratio total, bilirubin and serum electrolytes, were not significantly affected by either hypercholesterolemia or the concurrent supplementation with parsley seed methanolic extract and carob legume methanolic extract.

The significant decrease of the enzymatic and nonenzymatic antioxidants and decrease of lipid peroxidation as a result of induced hypercholesterolemia in serum, and heart and liver tissue homogenate of the positive control group is in agreement with previous studies [2,32-34]. The alteration in oxidative stress induced by reactive oxygen species (ROS) and impairments of the antioxidant system contributes to the incidence of hypercholesterolemia and subsequent cardiovascular diseases [5]. Superoxide dismutase (SOD) and glutathione peroxidase (GSH-Px) and non-enzymatic antioxidants play an important role in alleviating tissue damage due to the formation of free radicals [2].

Increasing the antioxidant enzymes activity and decreasing lipid peroxidation in serum, and liver and heart tissue homogenate with the concurrent supplementation with 20 $\mathrm{mg} / \mathrm{kg}$ bw of parsley seeds methanolic extract in G3 and carob legume methanolic extract in G4 for $8 \mathrm{w}$ is consistent with previous studies due to their content of phenolic and other antioxidant compounds $[11,15,35]$. Parsley seeds showed more effective to improve serum antioxidant enzymes and lipid peroxide than carob legume.

The increase in serum creatinine, uric acid, and urea as a result of induced hypercholesterolemia is consistent with Schaeffner et al. [36], El Rabey et al. [31] and Abulnaja et al. [2]. The elevated total cholesterol and the low density lipoproteins in particular were significantly associated with an increased risk of developing renal dysfunction. The alleviation of the adverse effects on kidney function with the concurrent supplementation with $20 \mathrm{mg} / \mathrm{kg}$ bw of parsley seed methanol extract in G3 and carob legume methanolic extract in G4 for $8 \mathrm{w}$ agrees with Haidari et al. [37].

In conclusion, parsley seed and carob legume methanolic extract succeeded in ameliorating the adverse effects resulted from hypercholesterolemia by increasing the antioxidant activity of the enzymatic antioxidants and the level of the nonenzymatic antioxidants, and decreasing the oxidative stress by lowering lipid peroxidation in hypercholesterolemic rats. Parsley appeared more efficient than carob.

\section{Acknowledgement}

The project was funded by the Deanship of Scientific Research (DSR), King Abdulaziz University, Jeddah, under grant No. (319 bi-34-). The authors, therefore, acknowledge with thanks DSR technical and financial support.

\section{References}

1. Despres JP, Lemieux I, Dagenais G, Cantin, B, Lamarche B. HDL-cholesterol as a marker of coronary heart disease risk: the Québec cardiovascular study. Atherosclerosis 2000; 153: 263-272.

2. Abulnaja KO, El Rabey HA. The efficiency of barley (Hordeum vulgare) bran in ameliorating blood and treating fatty heart and liver of male rats. Evid Based Compl Alt Med 2015; 740716.

3. El Rabey HA, Al-Seeni MN, Al-Ghamdi HB. Comparison between the hypolipidemic activity of parsley and carob in hypercholesterolemic male rats. Biomed Res Int 2017; 2017: 3098745.

4. Vaughan JG, Judd PA. Oxford Book of Health Foods (1st Edn.). Oxford University Press Inc., New York USA 2003.

5. Ismail TA, Soliman MM, Nassan MA, Mohamed DI. Antihypercholesterolemic effects of mushroom, chrysin, curcumin and omega-3 in experimental hypercholesterolemic rats. J Food Nutr Res 2015; 3: 77-87.

6. Custodio L, Fernandes E, Escapa AL, Lopez-Aviles S, Fajardo A, Aligue R, Albericio F, Romano A. Antioxidant activity and in vitro inhibition of tumor cell growth by leaf extracts from the carob tree (Ceratonia siliqua). Pharmaceut Biol 2009; 47: 721-728.

7. Kim EJ, Kim BH, Seo HS, Lee YJ, Kim HH, Son HH, Choi MH. Cholesterol-induced non-alcoholic fatty liver disease and atherosclerosis aggravated by systemic inflammation. PLoS One 2014; 9: 1-11.

8. Charles DJ. Antioxidant properties of spices, herbs and other sources (1st Edn.). Springer New York USA 2013.

9. Khatib S, Vaya J. Fig, Carob, Pistachio, and Health. Bioactive Foods in Promoting Health. Academic Press, San Diego 2010; 245-263.

10. Lewis A, Segal A. Hyperlipidemia and primary prevention of stroke: does risk factor identification and reduction really work? Curr Atheroscler Rep 2010; 12: 225-229.

11. Mahmood S, Hussain S, Malik F. Critique of medicinal conspicuousness of Parsley (Petroselinum crispum): a culinary herb of Mediterranean region. Pak J Pharm Sci 2014; 27: 193.

12. Kolarovic J, Popovic M, Zlinska J, Trivic S, Vojnovic M. Antioxidant activities of celery and parsley juices in rats treated with doxorubicin. Molecules 2010; 15: 6193-6204.

13. Battle L, Tous J. Carob tree (Ceratonia siliqua L.). Promoting the conservation and use of underutilized and neglected crops. 17. Institute of Plant Genetics and Crop 
Plant Research, Gatersleben / International Plant Genetic Resources Institute, Rome, Italy 1997.

14. Haber B. Carob fiber benefits and applications. Cereal Foods World 2012; 47: 365369.

15. Sebai H, Souli A, Chehimi L, Rtibi K, Amri M, El-Benna $\mathrm{J}$, Sakly M. In vitro and in vivo antioxidant properties of Tunisian carob (Ceratonia siliqua L.). J Med Plants Res 2013; 7: 85-90.

16. Adebayo EA, Ishola OR, Taiwo OS, Majolagbe ON, Adekeye BT. Evaluations of the methanol extract of Ficus exasperata stem bark, leaf and root for phytochemical analysis and antimicrobial. Afric J Plant Sci 2009; 3: 283-287.

17. Jain RC, Khubnani H. Khubnani A. Action of garlic on the hyperlipidemia of experimental induced immune complex disease in rabbits. Ind J Pharmacol 1997; 29: 255-257.

18. Peterson GL. A simplification of the protein assay method of Lowry et.al. which is more generally applicable. Analyt Biochem 1977; 83: 346-356.

19. Rebecca R. Associations of histories of depression and PMDD diagnosis with allopregnanolone concentrations following the oral administration of micronized progesterone. Psychoneuroendocrinology 2006; 31: 1208-1219.

20. Balistreri WF, Shaw LM. Liver function, Fundamentals of clinical chemistry (3rd Edn.). Philadelphia WB Saunders USA 1987; 729-761.

21. Fawcett JK, Scott JE. A rapid and precise method for the determination of urea. J Clin Pathol 1960; 13: 156-159.

22. Fossati P, Prencipe L, Berti G. Use of 3,5-dichloro-2hydroxybenzenesulfonic acid/4-aminophenazone chromogenic system in direct enzymic assay of uric acid in serum and urine. Clin Chem 1980; 26: 227-231.

23. Tietz NW. Fundamentals of clinical chemistry. W.B. Saunders, R.S. Philadelphia 1976.

24. Schoenfeld RG, Lewellen CJ. A colorimetric method for determination of serum chloride. Clin Chem 1964; 10: 533-539.

25. Terri AE, Sesin PG. Colorimetric determination of potassium in human Serum and plasma using sodium tetraphenyl boron. Amer J Clin Pathol 1958; 29: 86.

26. Beutler E, Duron O, Kelly BM. Improved method for the determination of blood glutathione. J Lab Clin Med 1963; 61: 882-888.

27. Aebi H. Catalase in vitro. Methods Enzymol 1984; 105: 121-126.

28. Nishikimi NA, Yogi K. Measurement of superoxide dismutase. Biochem Biophys Res Commun 1972; 46: 849-854.
29. Goldberg DM, Spooner RJ. Assay of glutathione reductase. Methods of enzymatic analysis (3rd Ed.). Verlag Chemie Deerfield Beach, Weinheim 1983; 258-265.

30. Satoh K. Serum lipid peroxide in cerebrovascular disorders determined by a new colorimetric method. Clinica Chimica Acta 1978; 90: 37-43.

31. El Rabey HA, Al-Seeni MN, Amer HM. Efficiency of barley bran and oat bran in ameliorating blood lipid profile and the adverse histological changes in hypercholesterolemic male rats. Biomed Res Int 2013; 263594.

32. Mahfouz MM, Kummerow F. Cholesterol-rich diets have different effects on lipid peroxidation, cholesterol oxides, and antioxidant enzymes in rats and rabbits. J Nutr Biochem 2000; 11: 293-302.

33. Balkan J, Dogru-Abbasoglu S, Aykac-Toker G, Uysal M. The effect of a high cholesterol diet on lipids and oxidative stress in plasma, liver and aorta of rabbits and rats. Nutr Res 2004; 24: 229-234.

34. Yang RL, Shi YH, Hao G, Li W, Le GW. Increasing oxidative stress with progressive hyperlipidemia in human: relation between malondialdehyde and atherogenic index. J Clin Biochem Nutr 2008; 43: 154-158.

35. El-Hajaji H, Lachkar N, Alaoui K, CherrahY, Farah A, Ennabili A, Bali B, Lachkar M. Antioxidant activity, phytochemical screening, and total phenolic content of extracts from three genders of carob tree barks growing in Morocco. Arabian J Chem 2011; 4: 321-324.

36. Schaeffner ES, Kurth T, Curhan GC, Glynn RJ, Rexrode KM, Baigent C, Buring JE, Gaziano JM. Cholesterol and the risk of renal dysfunction in apparently healthy men. $\mathrm{J}$ Am Soc Nephrol 2003; 14: 2084-2091.

37. Haidari F, Keshavarz SA, Mohammad, SM, Mahboob SA, Rashidi MR. Effects of parsley (Petroselinum crispum) and its flavonol constituents, kaempferol and quercetin, on serum uric acid levels, biomarkers of oxidative stress and liver xanthine oxidoreductase aactivity in oxonateinduced hyperuricemic rats. Iran. J Pharmaceut Res 2011; 10: 811 .

\section{*Correspondence to}

Haddad A. El Rabey

Biochemistry Department

University of Tabuk

Kingdom of Saudi Arabia 